\title{
A REVIEW
}

\section{A review on farmer producer organisations: A new dimension to the farmer centric approach}

\author{
Shridevi Valamannavar* and S. Sumanth ${ }^{1}$ \\ Department of Extension Education (Agri.), College of Agriculture, Assam Agricultural University, \\ Jorhat (Assam) India (Email: shreedevisv2010@gmail.com)
}

\begin{abstract}
Farmers are the backbone of our country. Since a decade number of small and marginal farmers keep on increasing. Due to the fragmented holding and improper management practices in farming inadequate access to market making them agriculture more unviable. Same time increasing demand for the quality and fresh food products is providing the greater opportunities to the farmers. Farmers Producers Organisations is the great ray of hope to tackle these above mentioned two problems effectively. It plays a greater role to narrow down the relationship between Agriculture and Marketing. The farmers who were registered in Farmers Producers Organisation get a good support from both state and central government; technically as well as financially. This approach is very helpful to small and marginal farmers to develop themselves in the global agricultural and to take control over market effectively. However, majority of these located in rural areas and suffer from the problems like Inadequate Professional Management and Manpower, poor start-up capital, lack of technically skilled man power, ineffective capacity building training programmes. There is a need to find the solution and to need bring policy changes to handle this problem to empower our farmers to and Indian economy too.
\end{abstract}

Key Words : Farmer producer organisation, Quality produce, Market growth, Opportunities

View Point Article : Valamannavar, Shridevi and Sumanth, S. (2019). A review on farmer producer organisations: A new dimension to the farmer centric approach. Internat. J. agric. Sci., 15 (1) : 212-216, DOI:10.15740/HAS/IJAS/15.1/212-216. Copyright@2019: Hind AgriHorticultural Society.

Article History : Received : 03.11.2018; Accepted : 27.12.2018

\footnotetext{
* Author for correspondence:

${ }^{1}$ Department of Agricultural Extension, Institute of Agriculture Visva-Bharati, Sriniketan (W.B.) India (Email: sumanthbandari1418@gmail.com)
} 